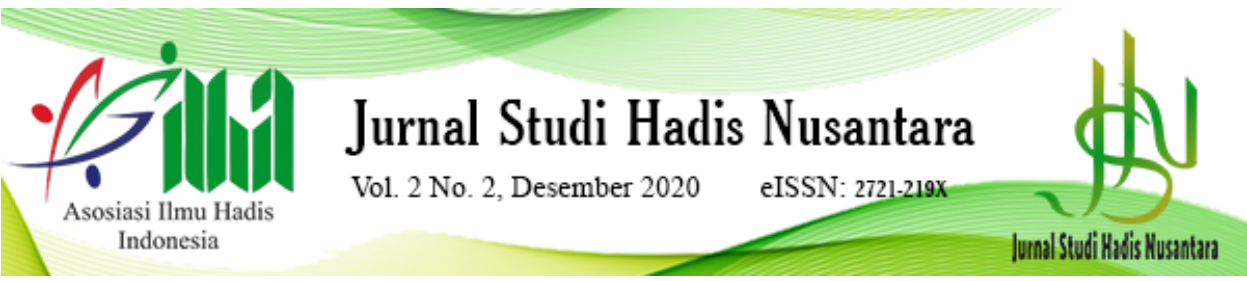

\title{
PROBLEMATIKA PENERAPAN KONTEKSTUALISASI HADIS TENTANG ANCAMAN ORANG YANG MENINGGALKAN SHALAT JUM'AT MASA PANDEMI COVID-19
}

\author{
Muhammad Alwi HS \\ UIN Sunan Kalijaga Yogyakarta \\ Email: muhalwihs2@gmail.com
}

\begin{abstract}
This article discusses the problems faced in the effort to apply to the contextualization of Hadith about the 'threat of people who leave the prayer of Friday', especially in the pandemic Covid-19 in Indonesia. This is based on the fact that state institutions, Indonesian Islamic Community Organizations, and scholars agree on the understanding that the Friday prayers can be left behind during the Covid-19 period. However, the fact in the field shows still very many societies who force to carry out the prayer on Friday. From here, this article shows, at least, four problems seen in the community, ie (1) the emergence of counter-hadith postulate (2) fearing out of the textual understanding of the Hadith, (3) contextualization of the Hadith to the exact application context, and (4) presence of the appreciation of the public to the other religious religion. Therefore, this paper concludes that it is necessary to deliver and the thickement of the contextual understanding of religious values to the public, for the dollains, both based on love and understanding, can be adopted as the context that applies. Contextual understanding of the 'threat of the threat to the person who leaves the Fray's prayer' must be accompanied by the contextual understanding of the religious alleged (Al-Qur'an and Hadith) associated with the sole understanding of the other.
\end{abstract}

Keywords: Hadith, contextual understanding, Covid-19, Friday prayers.

\begin{abstract}
Abstrak
Artikel ini membahas tentang problem yang dihadapi dalam upaya penerapan atas kontekstualisasi hadis tentang 'ancaman orang yang meninggalkan shalat Jum'at', khususnya pada masa pandemi Covid-19 di Indonesia. Hal ini berdasarkan kenyataan bahwa lembaga Negara, organisasi masyarakat Islam Indonesia, serta para ulama sepakat dalam pemahaman bahwa shalat Jum'at dapat ditinggalkan selama masa Covid-19. Akan tetapi, fakta di lapangan memperlihatkan masih sangat banyak masyarakat
\end{abstract}


yang memaksa untuk melaksanakan shalat Jum'at di masjid. Dari sini, artikel ini memperlihatkan, paling tidak, empat problem yang terlihat di masyarakat, yakni (1) Munculnya dalil hadis 'tandingan', (2) Takut keluar dari pemahaman tekstual hadis, (3) Kontekstualisasi hadis ke konteks yang tidak tepat, dan (4) Adanya resepsi performatif oleh masyarakat terhadap dalil-dalil agama lainnya. Karena itu, tulisan ini menyimpulkan bahwa perlu dilakukan penyampaian dan pembiasaan atas pemahaman kontekstual dalil-dalil agama kepada masyarakat, agar dalil-dalil, baik yang berdasarkan kecintaan maupun pemahaman, dapat disesuikan sebagaimana konteks yang mengitarinya. Pemahaman kontekstual atas hadis 'ancaman bagi orang yang meninggalkan shalat Jum'at' mesti dibarengi dengan pemahaman kontekstual atas dalil-dalil agama (Al-Qur'an dan Hadis) yang terkait dengannya, agar pemahaman tersebut tidak saling tumpang tindih.

Kata Kunci: Hadis, Pemahaman Kontekstual, Covid-19, Shalat Jum'at.

\section{Pendahuluan}

Presiden Indonesia, Joko Widodo, mengumumkan agar masyarakat Indonesia bekerja, belajar, dan beribadah di rumah ${ }^{1}$ sejak wabah Covid-19 menyebar. Mulai saat itu, cara beragama menjadi salah satu aspek kehidupan masyarakat yang ikut berubah. Salah satu bentuk konkrit berubahnya cara beragama adalah adanya instruksi untuk tidak melaksanakan shalat Jum'at berjama'ah di masjid dan ditutupnya masjid di berbagai wilayah Indonesia. Kondisi ini mengundang polemik diberbagai lapisan masyarakat. Banyak yang menolak tetapi tidak sedikit juga yang mematuhi perintah tersebut. Polemik tersebut tidak hanya sampai pada tahap wacana, diskusi, dan pembicaraan dikalangan awam maupun elit, tetapi sampai ada yang melakukan aksi demonstrasi menuntut dibolehkannya shalat Jumat berjama'ah di Masjid. Kondisi tersebut memunculkan inisiatif para pemuka agama, akademisi, hingga ulama besar Indonesia untuk memberi pemahaman kepada masyarakat tentang problem keagamaan di tengah Covid-19 tersebut.

M. Quraish Shihab, salah satu ulama besar Indonesia, cepat menyadari problem keagamaan masyarakat Indonesia ditengah pandemi Covid-19. Ia mengarang buku dengan judul Corona Ujian Tuhan (2020). ${ }^{2}$ M. Quraish Shihab hendak menegaskan bahwa Covid-19 adalah ujian dari Allah SWT kepada manusia. Dampaknya ialah ibadah yang biasa dilakukan di Masjid dapat dilakukan di rumah, seperti shalat lima waktu, shalat Jum'at, shalat Tarawih.

1 Setkab, "Minta Masyarakat Tenang Presiden Saatnya Bekerja Belajar Dan Beribadah Dari Rumah,” 2020, https://setkab.go.id/minta-masyarakat-tenang-presiden-saatnyabekerja-belajar-dan-beribadah-dari-rumah/.

2 M. Quraish Shihab, Corona Ujian Tuhan: Sikap Muslim Menghadapinya (Tangerang: Lentera Hati, 2020). 
Buku-buku lain yang merespon kehidupan keagamaan di tengah pandemik Covid-19 diantaranya adalah Fiqh Covid-19 karya Abdul Muta'ali (2020), ${ }^{3}$ Agama di Tengah Musibah karya Haidar Bagir (2020), ${ }^{4}$ Fikih Pandemi: Beribadah di Masa Wabah (2020) yang merupakan kumpulan tulisan dari beberapa akademisi yang berada di bawah naungan lembaga Nasaruddin Umar Office (NUO). ${ }^{5}$ Berbagai karya tersebut menunjukkan besarnya perhatian ulama dan akademisi terhadap kondisi pandemi Covid-19 di Indonesia. Buku-buku diatas berisi respon terhadap kebijakan, perintah, ataupun larangan dari pemerintah, baik daerah maupun pusat. Selain itu, karya-karya di atas berupaya mengakomodir persoalan pergeseran ibadah masyarakat dari masjid ke rumah. Secara umum, pandangan ulama, akademisi, dan pemerintah menghasilkan himbauan agar masyarakat menjalankan ibadah di rumah, bukan di masjid secara berjama'ah.

Tak hiraukan himbauan pemerintah, masih sangat banyak dijumpai masyarakat yang tetap melaksanakan shalat berjama'ah di Masjid, terutama shalat Jum'at. Hal ini memunculkan pertanyaan, apa problem yang dihadapi sehingga terjadi kontroversi dalam penerapan kontekstualisasi pemahaman keagaaman tersebut? Tulisan ini hendak menganalisis mengapa terjadi simpang siur antara menjalankan ibadah di masjid atau di rumah dalam konteks shalat Jum'at, termasuk faktor-faktor apa saja yang menyebabkan terjadinya pelanggaran atas arahan pemerintah dan ulama untuk tidak shalat jum'at di masjid.

Tulisan ini fokus pada kajian hadis dalam kaitannya dengan kontekstualisasi ajaran Islam di era pandemi Covid-19. Sepanjang penelusuran penulis, penelitian yang mendiskusikan Covid-19 dalam kaitannya dengan konteks keagamaan di Indonesia masih sangat sedikit. Penelitian tersebut seperti dilakukan oleh Muhammad Agus Mushodiq dan Ali Imran (2020), ${ }^{6}$ Dani Muhtada (2020), ${ }^{7}$ Saifuddin Zuhri Qudsy

3 Abdul Muta'ali, Fiqh Covid-19: Fleksibilitas Ibadah Dan Sosial Saat Pandemi Corona Berdasarkan Quran, Sunnah, Dan Analisis Semantik Pragmatik (Jakarta: Rajawali Press, 2020).

4 Haidar Bagir, Agama Di Tengah Musibah: Perspektif Spiritual (Jakarta: Nuralwala, 2020).

5 Fared F. Saenong and dkk, Fikih Pandemi: Beribadah Di Masa Wabah (Jakarta: NUO Publishing, 2020).

6 Muhammad Agus Mushodiq and Ali Imron, "Peran Majelis Ulama Indonesia Dalam Mitigasi Pandemi Covid-19: Tinjauan Tindakan Sosial Dan Dominasi Kekuasaan Max Weber," Salam: Jurnal Sosial \& Budaya 7, no. 5 (2020).

7 Dani Muhtada, “Agama Dan Mitigasi Wabah Covid-19," CSIS Indonesia, Pakarti Centre Building, Indonesia 10160, 2020, csis.or.id. 
dan Ahmad Sholahuddin (2020), ${ }^{8}$ dan Tasri (2020). ${ }^{9}$ Lebih jauh, berbagai penelitian tersebut belum menyentuh diskusi penyebaran Covid-19 dalam konteks ibadah di masjid, terutama shalat Jum'at. Dari sini, artikel ini akan menganalisis problematika penerapan atas kontekstualisasi hadis tentang shalat Jum'at. Adapun hadis yang dimaksud di sini adalah hadis tentang ancaman kafir bagi orang yang meninggalkan shalat Jum'at, yakni:

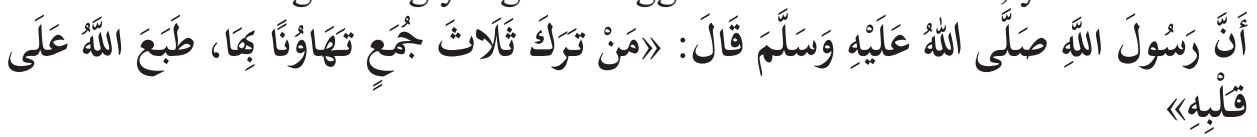

\section{Covid-19 dan Shalat Berjam'ah di Masjid}

Yuval Noah Harari dalam bukunya, Homo Deus, mengatakan bahwa wabah menjadi musuh terbesar manusia setelah kelaparan. Yuval menyebutkan berbagai wabah yang pernah terjadi dalam sejarah manusia seperti Maut Hitam pada dekade $1330,{ }^{10}$ virus Cacar (smallpox) pada tahun $1520,{ }^{11}$ Flu Spanyol pada tahun $1918 .{ }^{12}$ Yuval kemudian mengatakan bahwa "sangat mungkin epidemi besar akan terus membahayakan manusia pada masa depan..." 13 Dengan demikian, sejarah manusia pada dasarnya telah banyak diliputi oleh wabah mematikan, termasuk pandemi Covid-19. Virus Corona, yang semula bernama 2019 novel coronavirus $(2019-\mathrm{nCoV}),{ }^{14}$ merupakan salah satu virus yang dapat menyebabkan penyakit terhadap manusia, seperti infeksi saluran pernapasan, mulai dari flu biasa hingga penyakit serius yakni Middle East Respiratory Syndrome (MERS) dan sindrom pernafasan akut berat/ Servere Acute Respiratory Syndrome (SARS). Covid-19 termasuk virus jenis baru, yang ditemukan atau tersebar pertama kali di Wuhan, China pada Desember 2019. ${ }^{15}$

Organisasi Kesehatan Dunia (WHO) menyatakan bahwa penyebaran Covid-19 dari satu orang ke orang lain sangat cepat, terutama ketika sedang 8 Saifuddin Zuhri Qudsy and Ahmad Sholahuddin, "Kredibilitas Hadis Dalam Covid-19: Studi Atas Bazl Al-Ma'un Fi Fadhil Al-Thaun Karya Ibnu Hajar Al-Asqalany," Al-Quds: Jurnal Studi Al-Qur'an Dan Hadis 4, no. 1 (2020).

9 Tasri, "Hikmah Di Tengah Wabah Virus Corona Dalam Tinjauan Hukum Islam," Qiyas 5, no. 1 (2020).

10 Yuval Noah Harari, Homo Deus: Masa Depan Umat Manusia (Jakarta: Pustaka Alvabet, 2018). hlm 7.

11 Harari, Homo Deus: Masa Depan Umat Manusia. hlm 9.

12 Harari, Homo Deus: Masa Depan Umat Manusia. hlm 10.

13 Harari, Homo Deus: Masa Depan Umat Manusia. hlm 15.

14 Adityo Susilo and dkk, "Corona Virus Disease 2019: Tinjauan Literatur Terkini," Jurnal Penyakit Dalam Indonesia 7, no. 1 (2020): 45.

15 "No Title," accessed July 28, 2020, https://covid19.kemkes.go.id/situasi-infeksiemerging/info-corona-virus/tanya-jawab-coronavirus-disease-covid-19-qna-update-6maret-2020. 
berdekatan, bersentuhan, dan berkumpul. ${ }^{16}$ Ketahanan Covid-19 ketika berada di tubuh manusia, benda mati, dan udara, berbeda-beda. Covid-19 dapat bertahan selama 1-14 hari pada tubuh manusia. Orang yang terpapar Covid-19 ada yang mengalami gejala dan tanpa gejala. ${ }^{17}$ Ketiadaan gejala menyulitkan identifikasi orang yang sedang terjangkit Covid-19. Upaya pencegahan dan penanggulangan Covid-19 dilakukan melalui himbauan pada masyarakat agar tetap tinggal di rumah. Apabila tidak ada urusan sangat penting di luar maka sebaiknya berdiam diri di rumah. Saat berada di area publik sebaiknya aktif memakai hand sanitizer dan tidak sembarangan menyentuh benda. ${ }^{18}$ Menjaga jarak menjadi salah satu kunci penting dalam memutus penyebaran Covid-19 tersebut.

Lebih jauh, sebagai gerakan atau program penekanan atas penyebaran virus tersebut, pemerintah segera menetapkan dan menyampaikan kepada masyarakat untuk melakukan menjaga jarak atau sosial distancing yang kemudian diganti menjadi fisical distancing. Saat yang sama, sebagai upaya menjaga jarak antar orang menyebabkan berbagai kegiatan yang dapat mengumpulkan banyak orang ditiadakan, termasuk ibadah shalat berjama'ah di masjid. Pemerintah Pusat melalui Menteri Kesehatan mengeluarkan Peraturan Menteri Kesehatan Republik Indonesia Nomor 9 Tahun 2020 tentang Pedoman Pembatasan Sosial Berskala Besar dalam Rangka Percepatan Penanganan Corona Virus Disease 2019 (Covid-19), ${ }^{19}$ yang merupakan bentuk nyata dari upaya pembatasan dan pemberhentian atas penyebaran Covid-19 di masyarakat seluruh wilayah di Indonesia. Aturan ini kemudian diteruskan oleh seluruh pemerintah daerah untuk melakukan pembatasan kegiatan yang mengumpulkan banyak orang. Hal ini bersinggungan dengan hadis yang menganjurkan umat Islam untuk datang ke masjid dan melaksanakan shalat Jum'at berjama'ah. Adapun redaksi lengkap hadis yang dimaksud adalah:

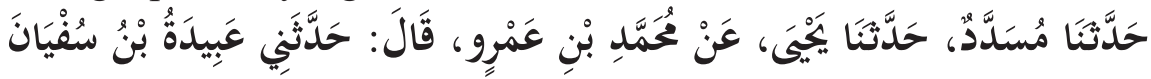

16 "No Title," accessed July 28, 2020, https://www.kompas.com/global/ $\mathrm{read} / 2020 / 03 / 12 / 001124570 /$ who-umumkan-virus-corona-sebagai-pandemi-global. 17 "No Title." accessed July 28, 2020, https://covid19.kemkes.go.id/situasi-infeksiemerging/info-corona-virus/tanya-jawab-coronavirus-disease-covid-19-qna-update-6maret-2020.

18 Ethan Siegel, "Tiga Cara Sains Membimbing Kita Melewati Pandemi Covid-19," in Yuval Noah Harari, et al: Wabah, Sains, Dan Politik translated by Antinomi Institute (Jakarta: Penerbit Antinomi, 2020), 3.

19 Menteri Kesehatan Republik Indonesia, "Peraturan Menteri Kesehatan Republik Indonesia Nomor 9 Tahun 2020 Tentang Pedoman Pembatasan Sosial Berskala Besar Dalam Rangka Percepatan Penanganan Corona Virus Disease 2019 (Covid-19)," Pub. L. No. Permenkes RI Nomor 9 Tahun 2020 (2020). 


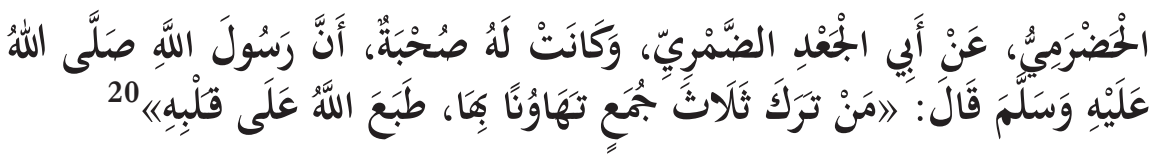

Artinya:

"Diceritakan kepada kami Musaddad, diceritakan kepada kami Yahya, dari Muhammad bin Amr, ia berkata: Diceritakan kepadaku Abidah bin Sufyan Al-Hadhramiy, dari Abi Al-Ja'd Al-Dhamriy, sesungguhnya Rasulullah SAW bersabda: Siapa yang meninggalkan shalat Jum'at tiga kali karena meremehkan, niscaya Allah menutup hatinya"

Dalam redaksi lainnya mengatakan:

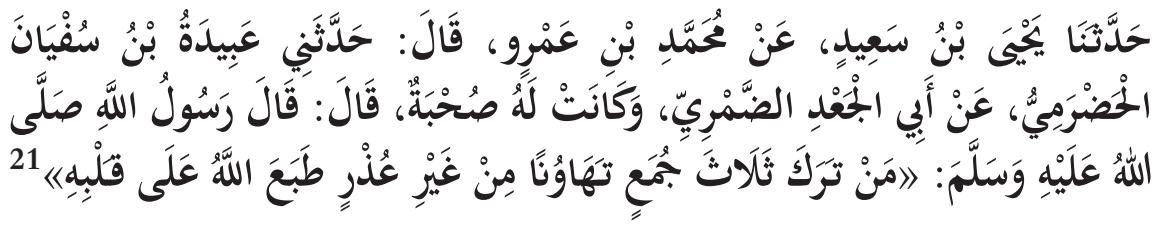

Artinya:

"Diceritakan kepada kami Yahya bin Sa'id, dari Muhammad bin Amr, ia berkata: Diceritakan kepadaku Abidah bin Sufyan Al-Hadhramiy, dari Abi Al-Ja'd Al-Dhamriy, sesungguhnya Rasulullah SAW bersabda: Siapa yang meninggalkan shalat Jum'at tiga kali karena meremehkan, niscaya Allah menutup hatinya"

Sampai di sini, penulis akan berfokus pada pemahaman matan hadis di atas. Hal ini dikarenakan sepanjang penyebaran atas pemahaman hadis tersebut dalam masyarakat serta dikutip atau disampaikan oleh ulama dan da'i, semuanya hanya berfokus pada matan hadis. Dengan demikian, sekalipun hadis tersebut misalnya terdapat kelemahan dari segi keshahihan sanad, tetapi hadis tersebut tetap mesti didiskusikan, karena ia telah menyebar dan mempengaruhi kehidupan beragama umat Islam di Indonesia, khususnya sepanjang masa Covid-19. Selanjutnya, di lihat dari matannya, hadis tersebut mengandung pemahaman bahwa orang yang tidak melaksanakan shalat Jum'at tiga kali, maka akan dikunci hatinya oleh Allah SWT. Lebih jauh, mereka yang mendapat ancaman atas siksaan dalam hadis tersebut adalah jika meninggalkan shalat Jum'at dengan sengaja atau bermaksud meremehkannya.

20 Sunan Abi Dawud, “Ancaman Dalam Meninggalkan Shalat Jum'at Nomor Hadis 1052," n.d. berdasarkan software Maktabah Syamilah.

21 Musnad Ahmad, “Abi Ja'd Al-Dhamriy, Nomor Hadis 15498," n.d. berdasarkan software Maktabah Syamilah. 


\section{Pemahaman Kontekstual Hadis: Dari Anjuran ke Larangan}

Sebelumnya telah dijelaskan problem yang dihadapi oleh umat Islam dalam shalat, yaitu melaksanakan shalat Jum'at berjama'ah di masjid pada era pamdemi Covid-19. Sebagai tindakan yang mengumpulkan banyak orang, shalat berjama'ah di masjid menjadi salah satu larangan yang dikeluarkan oleh pemerintah. Dari larangan tersebut, muncul upaya memberikan pemahaman kepada masyarakat dari segi landasan keagamaan, seperti dilakukan kontekstualisasi atas hadis ancaman bagi orang yang meninggalkan shalat Jum'at sebanyak tiga kali. Majelis Ulama Indonesia (MUI) selaku pemangku otoritas keagamaan di Indonesia, dapat dikategorikan sebagai pelopor munculnya pemahaman kontekstual atas hadis tentang ancaman meninggalkan shalat Jum'at tiga kali berturut-turut. Dalam hal ini, MUI mengeluarkan Fatwa Majelis Ulama Indonesia Nomor: 14 Tahun 2020 tentang Penyelenggaran Ibadah dalam Situasi tejadi Wabah Covid-19, yang di antara isinya adalah sebagai berikut:

Orang yang telah terpapar virus Corona, wajib menjaga dan mengisolasi diri agar tidak terjadi penularan kepada orang lain. Baginya shalat Jum'at dapat diganti dengan shalat Zuhur, karena shalat Jum'at merupakan ibadah wajib yang melibatkan banyak orang sehingga berpeluang terjadinya penularan virus secara massal. Baginya haram melakukan aktifitas ibadah sunnah yang membuka peluang terjadinya penularan, seperti Jama'ah shalat lima waktu/ rawatib, shalat Tarawih dan Ied di masjid atau tempatumum lainnya, serta menghadiri pengajian umum dan tabligh akbar. ${ }^{22}$

Tidak hanya dari lembaga negara, tokoh agama pun ikut serta mengeluarkan pandangannya tentang kontekstualisasi hadis di atas. M. Quraish Shihab mengatakan bahwa semua yang berbentuk larangan atau perintah mesti dilaksanakan agar tercapai maqashid syariah. M. Quraish Shihab memerhatikan fenomena penyebaran Covid-19 yang sangat cepat ketika orang-orang berkumpul, yang berpotensi menyebabkan kematian. Ia berpendapat bahwa ancaman atas ditutupnya hati seseorang yang meninggalkan shalat Jum'at tiga kali berturut-turut tidak tergolong dalam konteks pandemi Covid-19 saat ini. Hal ini karena meninggalkan shalat jum'at karena khawatir terkena Covid-19 merupakan uzur yang

22 Majelis Ulama Indonesia, "Fatwa Majelis Ulama Indonesia Nomor: 14 Tahun 2020 Tentang Penyelenggaran Ibadah Dalam Situasi Terjadi Wabah Covid 19," Pub. L. No. Fatwa Majelis Ulama Indonesia Nomor 14 Tahun 2020 (2020). 
dapatditerima oleh Agama. ${ }^{23} 24$

Ormas Islam Indonesia seperti Pengurus Besar Nahdlatul Ulama (PBNU) mengeluarkan keputusan dalam Bahtsul Masail tentang shalat Jum'at, khususnya pada daerah yang terjangkit Covid-19. Salah satu keputusan tersebut adalah sebagai berikut: ${ }^{25}$

Orang-orang yang sudah tahu bahwa dirinya positif mengidap virus korona (Covid-19), maka virus korona bukan hanya uzur (alasan) yang membolehkan yang bersangkutan meninggalkan shalat Jum'at (melainkan juga menjadi larangan baginya untuk menghadiri shalat Jum'at). Dalam konteks itu, berlaku hadits La Dlarara wa La Dhirar (tidak boleh melakukan tindakan yang dapat membahayakan diri sendiri dan orang lain).

Akan tetapi apabila dia tetap ikut melaksanakan shalat Jum'at atau jama'ah di masjid maka shalatnya tetap sah, karena meskipun dia dilarang namun larangannya tidak kembali kepada sesuatu yang dilarang yaitu shalat, melainkan karena faktor eksternal, yaitu menimbulkan bahaya kepada orang lain.

Ormas Islam Indonesia PP Muhammadiyah mengeluarkan maklumat tentang wabah Covid-19 sebagai berikut: ${ }^{26}$

Kegiatan-kegiatan ibadah seperti shalat berjama'ah dan shalat Jum'at di masjid tetap dilaksanakan dengan ketentuan sebagai berikut:

Bagi yang sakit disarankan untuk beribadah di rumah.

Apabila dipandang darurat, pelaksanaan shalat Jumat dapat diganti dengan shalat dhuhur di rumah, dan pelaksanakan shalat berjamaah dapat di rumah.

Ulama seperti Abdul Somad juga berupaya mengkontekstualisasikannya dengan menjelaskan secara spesifik term tahauna (karena menyepelekan). Abdul Somad mengatakan bahwa wabah Covid-19 menjadi penyebab umat Islam tidak termasuk di dalamnya. Hal ini dikhawatirkan jika ada orang yang positif Covid-19 kemudian menular kepada jama'ah lainnya. ${ }^{27}$ Pandangan spesifik lain tentang term tahauna (meremehkannya) muncul dari Das'ad Latif. Ia mengatakan bahwa ulama 23 M. Quraish Shihab, Corona Ujian Tuhan: Sikap Muslim Menghadapinya (Tangerang: Lentera Hati, 2020).

24 Kanal youtube Najwa Shihab, "Wabah Corona, Wajibkah Jumatan Dan Shalat Di Masjid?," 2020. ", dipublikasikan pada 19 Maret 2020, diakses pada 24 Juli 2020.

25 "No Title," accessed July 29, 2020, https://www.inews.id/new/nasional/3-keputusanbahtsul-masail-pbnu-soal-shalat-jumat-di-daerah-terjangkit-covid-19.

26 "No Title," accessed July 29, 2020, http://m.muhammadiyah.od.id/id/new-18625detail-maklumat-pp-muhammadiyah-tentang-wabah-covid-19.html.

27 Kanal youtube tvOneNews, "Ustadz Abdul Somad Angkat Bicara Soal Muslim Tak Sholat Jumat 3X Berturut-Turut Karena Corona,” 2020. diakses pada 24 Juli 2020. 
tafsir-hadis memahami tahauna dengan dua makna, (1) ditinggalkan tiga kali secara berturut-turut, (2) ditinggalkan tiga kali selama seumur hidupnya. Apabila keduanya dilakukan tanpa ada alasan, maka hal inilah yang mendapatkan ancaman ditutup hatinya. Konteks saat ini, wabah Covid-19, menjadi unsur daruriyat terutama menjaga jiwa dalam maqashid syariah. Dengan demikian, hukum meninggalkan shalat jum'at saat ini adalah boleh dan tidak termasuk orang-orang yang dimaksud dalam hadis tersebut. ${ }^{28}$

Masih sangat banyak ulama dan da'i yang menyampaikan pendapatnya atas pemahaman hadis ancaman meninggalkan shalat Jum'at tersebut di masa pandemi Covid-19. Semua pemahaman tersebut mengarah kepada upaya memperhatikan aspek maqashid syariah, khususnya menjaga jiwa manusia atau menghilangkan bahaya atas Covid-19. Semua pemahaman yang ada sepakat melakukan kontekstualisasi hadis, yakni dengan melibatkan konteks era pandemi ini ke dalam diskusi hadis yang disampaikannya. Menariknya, pemahaman kontekstual ini muncul dari berbagai kalangan ulama hingga da'i yang cenderung memahami teks agama secara tekstual. Akan tetapi, sekalipun telah berupaya dipahami secara kontekstual dan diberikan pengertian kepada masyarakat awam, ternyata belum mendapat apresiasi oleh masyarakat itu sendiri. Pada bahasan selanjutnya akan dibahas berbagai problem yang dimaksud.

\section{Problematika Larangan Shalat Berjama'ah di Masjid}

Telah dibahas sebelumnya bahwa hadis tentang ancaman bagi orang yang meninggalkan shalat Jum'at tidak dapat diterapkan dan dikenakan kepada umat Islam pada masa wabah Covid-19. Akan tetapi, pemahaman kontekstual hadis tersebut tidak banyak diapresiasi masyarakat. Ada empat faktor utama problematika penerapan kontekstual hadis, yakni Pertama, munculnya dalil hadis 'tandingan'; Kedua, ketakutan untuk keluar dari pemahaman tekstual; Ketiga, konteks yang tidak tepat; Keempat, terjadi performasi masyarakat atas dalil-dalil agama lainnya terhadap keutaman masjid. Berikut penjelasan lebih jauh atas keempat problem tersebut.

\section{Kritik Hadis; Definisi, Urgensi, dan Historisitas}

Problem utama yang dapat dijumpai dalam pelarangan shalat berjama'ah di masjid adalah munculnya orang-orang yang menyebarkan ajaran pentingnya shalat di masjid sekalipun di tengah wabah Covid-19, yang mengatasnamakan hadis Nabi. Nazier Millionaire, salah satu murid Abdul Somad dalam akun youtube-nya, merespon fenomena larangan shalat berjama'ah di masjid dengan mengutip hadis, yakni "Orang yang 28 Kanal Youtube tvOneNews, “Tidak Sholat Jumat Tiga Kali Jadi Kafir? Ustadz Das'ad Latif Menjawab I,” 2020. diakses pada 24 Juli 2020. 
melakukan shalat Shubuh di Masjid secara berjama'ah akan mendapat perlindungan dari Allah langsung". Pengungkapan hadis ini, oleh Nizar, dijadikan landasan untuk menyuarakan pandangannya atas tetap berlangsungnya shalat berjama'ah di masjid, sebagaimana yang telah diamalkan oleh masyarakat Aceh, tepatnya di kabupaten Aceh Timur. ${ }^{29}$ Sepanjang penelusuran penulis, tidak menemukan redaksi lengkap hadis yang dikutip oleh Nazier tersebut. Hadis yang paling mendekati redaksi tersebut terdapat dalam riwayat Shahih Muslim, yakni sebagai berikut:

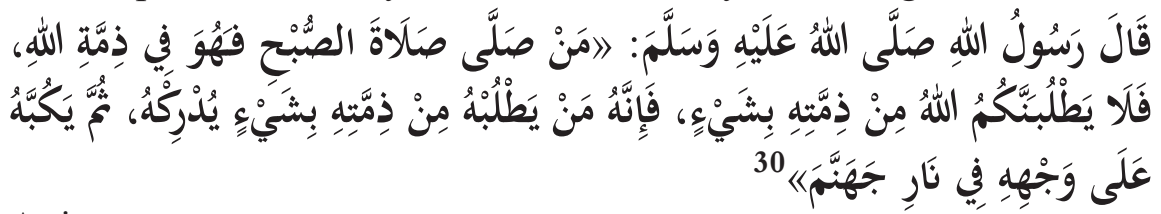

Artinya:

"Rasulullah SAW bersabda: Barangsiapa yang shalat Shubuh maka dia berada dalam jaminan Allah. Oleh karena itu, jangan sampai Allah menuntut sesuatu kepada kalian dari jaminan-Nya. Karena siapa yang Allah menuntutnya dengan sesuatu dari jaminan-Nya, maka Allah pasti akan menemukannya di atas wajahnya dalam neraka jahanam" Penulis telah melakukan penelusuran takhrij hadis terkait hadis yang serupa dengan hadis di atas seperti dalam kitab Sunan At-Tirmidzi nomor hadis $222^{31}$, dalam kitab Sunan Ibn Majah nomor hadis $3945^{32}$, Musnad Ahmad nomor hadis $18803^{33}$. Akan tetapi, penulis tidak menemukan redaksi hadis yang di dalamnya terdapat ungkapan "shalat Subuh di masjid", sebagaimana pemaparan Nazier Millionaire di atas. Penambahan "di masjid" dalam ungkapan Nazier tersebut menunjukkan adanya pemaksaan atas legalitas narasi yang disampaikannya. Kondisi ini berpotensi mengantarkan pemirsanya agar shalat berjama'ah di masjid tetap dapat dilaksanakan walaupun dalam keadaan wabah Covid-19.

\section{Aspek-aspek Pengujian dalam Kritik Hadis}

29 Kanal Youtube Nazier Millionaire, "Penutupan Masjid Dan Lockdown Tidak Berlaku Di Aceh I Nazier Millionaire \#ustadzabdulsomad," 2020. diakses pada 24 Juli 2020.

30 Shahih Muslim, Keutamaan Shalat Isya Dan Shubuh Berjama'ah, Nomor Hadis 262, n.d.

31 Adapun redaksi hadisnya adalah:

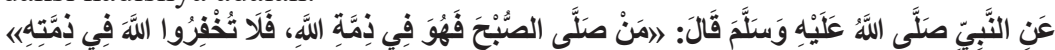

32 Adapun redaksi hadisnya adalah:

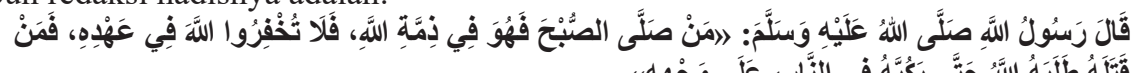

33 Adapun redaksi hadisnya adalah:

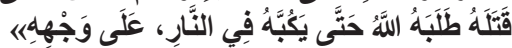

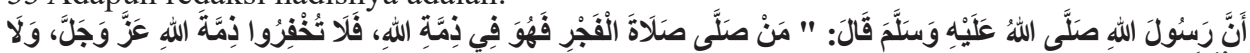

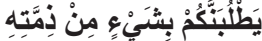


Pemahaman hadis secara tekstual sangat mungkin terjadi. Hadis sebagai sebuah teks tulis memunculkan dua kehendak, yakni dipahami secara tekstual atau didalami dengan pemahaman konteks. Dalam konteks ini, hadis tentang ancaman bagi orang yang meninggalkan shalat Jum'at sebanyak tiga kali banyak dipahami secara tekstual. Lebih jauh, pemahaman tekstual tersebut cenderung berhenti pada 'akibat' meninggalkan shalat Jum'at, bukan pada illat hadis tersebut. Boleh jadi, kecenderungan tersebut disebabkan oleh ketidakmampuan menggali lebih jauh pemahaman atas illat hadis tersebut. Kondisi ini dikarenakan pemahaman tekstual ini terjadi di kalangan masyarakat awam.

\section{Kontekstualisasi hadis ke konteks yang tidak tepat}

Problem dalam penerapan pemahaman kontekstual atas hadis agar masyarakat tidak melaksanakan shalat Jum'at di masjid ada pada persoalan konteks itu sendiri. Walaupun pemahaman kontekstual tersebut memberi solusi keagamaan di era wabah Covid-19, tidak semua daerah di Indonesia yang menghadapi konteks wabah Covid-19 ini. Konteks-konteks yang sangat minim atau bahkan tidak terkena Covid-19 berada di daerah pedalaman, desa terpencil, pulau kecil yang jauh dari daratan. Pemahaman kontekstual atas hadis tersebut tetap diberlakukan walaupun, daerah-daerah tersebut tidak ditemukan kasus penyebaran Covid-19. Artinya, terjadi ketidaktepatan dalam mengkontekstualisasikan hadis tentang ancaman meninggalkan shalat Jum'at di tengah masyarakat. Keadaan seperti ini dapat mengakibatkan terjadinya Instruksi-Tekstual dalam kehidupan beragama di masyarakat. Intruksi-Tekstual yang dimaksud ialah upaya penerapan dan pemaksaan pemahaman hadis secara tekstual. Sehingga, hadis yang semula dipahami secara kontekstual dengan konteks yang terkena wabah Covid-19, seketika menjadi tekstual disebabkan diterapkan pada konteks yang tidak tepat.

\section{Resepsi performatif masyarakat terhadap dalil-dalil agama}

Resepsi performatif menjadi problem yang banyak terlihat. Masyarakat banyak yang memaksakan diri melaksanakan shalat Jum'at di Masjid. Menurut pemahamannya, shalat Jum'at diistimewakan dibanding shalat fardu lainnya. Kondisi ini terlihat dengan adanya fenomena masyarakat yang senantiasa meramaikan shalat Jum'at, sekalipun setiap 
harinya tidak begitu memperhatikan shalat fardu lainnya. Keadaan ini disebabkan banyak dalil-dalil agama yang disampaikan sebelum shalat Jum'at, sehingga membentuk pemahaman dan kebiasaan (baca: tradisi) masyarakat terhadap shalat Jum'at. Dengan kata lain, masyarakat cenderung atau sedang mengalami resepsi performasi terhadap dalil agama, baik AlQur'an maupun Hadis. Berikut dalil-dalil yang dimaksud:
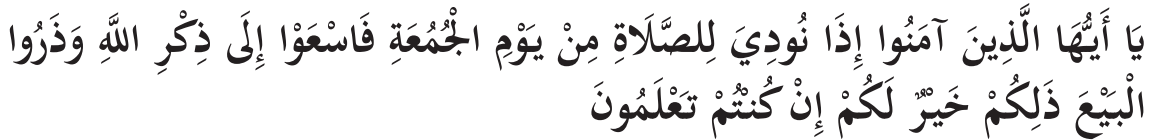

Artinya:

"Wahai orang-orang yang beriman. Apabila telah diseru untuk melaksanakan shalat pada hari Jum'at, maka segeralah kamu mengingat Allah dan tinggalkanlah jual beli. Yang demikian itu lebih baik bagimu jika kamu mengetahui” (QS. Al-Jumu'ah: 9).

Ayat di atas sangat banyak -jika enggan mengatakan semuanyasetiap hari dan setiap masjid dilantunkan, baik dibaca ketika khutbah maupun shalat. Kebiasaan membaca dan menyampaikan ayat ini kepada masyarakat membentuk resepsi performasi di kalangan masyarakat untuk mengistimewakan shalat Jum'at.

Selain itu, dalil lainnya yang juga membentuk resepsi performatif masyarakat terhadap shalat Juma't berjama'ah di masjid adalah keutamaan shalat berjama'ah, yakni:

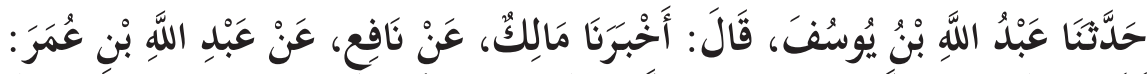

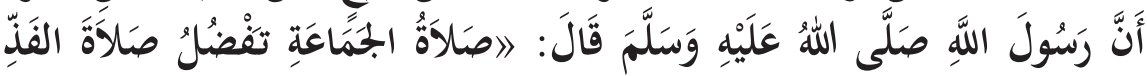

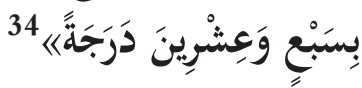

Artinya:

"Diceritakan kepada kami Abdullah ibn Yusuf, ia berkata: Diberitakan kepada kami Malik, dari Nafi', dari Abdullah bin Umar, sesungguhnya Rasulullah SAW bersabda: Shalat berjama'ah lebih mulai daripada shalat sendirian dengan dua puluh tujuh derajat" (HR. Bukhari).

Dalil lain yang mempengaruhi masyarakat untuk tidak lepas dari shalat berjama'ah di masjid adalah hadis yang mengemukakan keistimewaan masjid sebagai tempat yang paling dicintai oleh Allah, yakni:

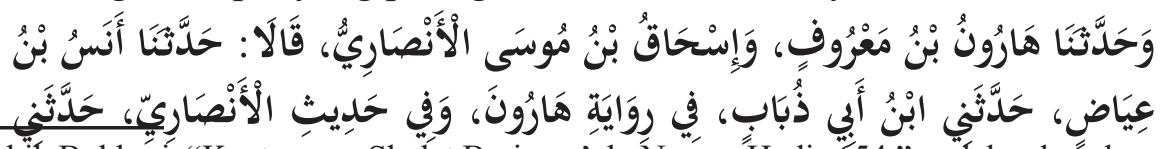
34 Shahih Bukhari, "Keutamaan Shalat Berjama'ah, Nomor Hadis 654," n.d, berdasarkan software Maktabah Syamilah. 


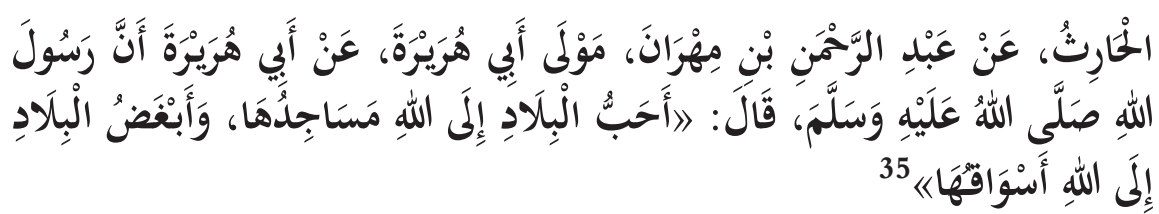

Artinya:

"Diceritakan kepada kami Harun bin Ma'ruf, Ishaq bin Musa A1Ansari, keduanya berkata: "Diceritakan kepada kami Anas bin 'Iyadh, diceritakan kepadaku Ibnu Abi Dzubab, dalam riwayat Harun, dan dalam Hadis Al-Anshari, diceritakan kepadaku Al-Harits, dari Abdurrahman bin Muhran, Maula Abi Hurairah, dari Abi Hurairah, sesungguhnya Rasulullah SAW bersabda: "Tempat yang paling dicintai Allah adalah pada masjid-masjidnya, dan tempat yang paling dimurkai Allah adalah pasar-pasarnya" (HR. Muslim).

Hadis di atas kerap dijumpai di masjid-masjid, baik dalam bentuk kaligrafi maupun alarm jadwal shalat. Biasanya, di masjid-masjid hanya mencantumkan versi terjemahan hadisnya. Informasi keutamaan masjid dalam hadis tersebut berhasil membentuk resepsi performatif di masyarakat untuk menghormati masjid. Banyak tersebar pemahaman bahwa masjid adalah rumah Allah yang di dalamnya terdapat keselamatan, kedamaian, berkah, dan segala kebaikan, sehingga masjid menjadi tempat paling aman sekaligus nyaman bagi umat Islam. Tidak heran ketika hendak dilakukan program penutupan masjid di masa wabah Covid-19, banyak masyarakat yang menolaknya.

\section{Penutup}

Walaupun upaya kontekstualisasi hadis di era Covid-19 telah dilakukan oleh lembaga, ulama, dan orang-orang yang ahli atasnya, namun problem penerapannya tidak dapat dielakkan, baik problem yang bersifat pemahaman maupun resepsi performasi (kecintaan). Berbagai masalah tersebut mengindikasikan masih perlunya upaya sosialisasi dan negosiasi tentang solusi atas problem Covid-19 kepada masyarakat, serta pemahaman yang intensif atas kebolehan meninggalkan shalat Jum'at berjama'ah di masjid. Penerapan pemahaman kontekstual hadis nampaknya sulit terpenuhi jika hal tersebut dilakukan dalam bentuk intruksi atau hanya menyampaikan di forum-forum atau media umum. Pemahaman kontekstual tersebut mesti disampaikan secara membumi, langsung kepada masyarakat. Melalui cara demikian, masyarakat dapat memahami problem, solusi, dan konteks yang

35 Shahih Muslim, "Keutamaan Di Mushola Setelah Shalat Shubuh, Nomor Hadis 288," n.d, berdasarkan software Maktabah Syamilah. 
dihadapinya secara jelas. Pemahaman kontekstual hadis, dari ancaman menjadi kebolehan meninggalkan shalat Jum'at, mesti diimbangi dengan pemahaman kontekstual atas dalil-dalil agama (Al-Qur'an dan Hadis) lainnya yang terkait dengan isu shalat Jum'at di Masjid. Dalil-dalil agama yang dimaksud seperti ayat tentang perintah shalat Jum'at (Al-Jumuah: 9), hadis tentang keutamaan masjid, dan hadis tentang keutamaan shalat berjama'ah. Dalil-dalil tersebut perlu diberi penjelasan seiring dengan upaya memutus mata rantai penyebaran Covid-19 di Masjid, sehingga umat Islam mampu dan terbiasa memahami dalil-dalil agama secara kontekstual. Wallahu A'lam.

\section{Daftar Pustaka}

Bagir, Haidar. Agama Di Tengah Musibah: Perspektif Spiritual. Jakarta: Nuralwala, 2020.

Harari, Yuval Noah. Homo Deus: Masa Depan Umat Manusia. Jakarta: Pustaka Alvabet, 2018.

Kanal Youtube Nazier Millionaire. "Penutupan Masjid Dan Lockdown Tidak Berlaku Di Aceh I Nazier Millionaire \#ustadzabdulsomad," 2020.

Kanal youtube tvOneNews. "Ustadz Abdul Somad Angkat Bicara Soal Muslim Tak Sholat Jumat 3X Berturut-Turut Karena Corona,” 2020.

Kanal Youtube tvOneNews. "Tidak Sholat Jumat Tiga Kali Jadi Kafir? Ustadz Das'ad Latif Menjawab I," 2020.

Majelis Ulama Indonesia. Fatwa Majelis Ulama Indonesia Nomor: 14 Tahun 2020 Tentang Penyelenggaran Ibadah dalam Situasi Terjadi Wabah Covid 19, Pub. L. No. Fatwa Majelis Ulama Indonesia Nomor 14 Tahun 2020 (2020).

Menteri Kesehatan Republik Indonesia. Peraturan Menteri Kesehatan Republik Indonesia Nomor 9 Tahun 2020 tentang Pedoman Pembatasan Sosial Berskala Besar dalam Rangka Percepatan Penanganan Corona Virus Disease 2019 (Covid-19), Pub. L. No. Permenkes RI Nomor 9 Tahun 2020 (2020).

Muhtada, Dani. “Agama Dan Mitigasi Wabah Covid-19.” CSIS Indonesia, Pakarti Centre Building, Indonesia 10160, 2020. csis.or.id.

Mushodiq, Muhammad Agus, and Ali Imron. "Peran Majelis Ulama Indonesia Dalam Mitigasi Pandemi Covid-19: Tinjauan Tindakan Sosial Dan Dominasi Kekuasaan Max Weber." Salam: Jurnal Sosial \& Budaya 7, no. 5 (2020).

Musnad Ahmad. “Abi Ja'd Al-Dhamriy, Nomor Hadis 15498," n.d. 
Muta'ali, Abdul. Fiqh Covid-19: Fleksibilitas Ibadah Dan Sosial Saat Pandemi Corona Berdasarkan Quran, Sunnah, Dan Analisis Semantik Pragmatik. Jakarta: Rajawali Press, 2020.

"No Title." Accessed July 28, 2020. https://covid19.kemkes.go.id/situasiinfeksi-emerging/info-corona-virus/tanya-jawab-coronavirusdisease-covid-19-qna-update-6-maret-2020.

"No Title." Accessed July 28, 2020. https://www.kompas.com/global/ $\mathrm{read} / 2020 / 03 / 12 / 001124570 /$ who-umumkan-virus-corona-sebagaipandemi-global.

"No Title." Accessed July 29, 2020. https://www.inews.id/new/nasional/3keputusan-bahtsul-masail-pbnu-soal-shalat-jumat-di-daerahterjangkit-covid-19.

"No Title." Accessed July 29, 2020. http://m.muhammadiyah.od.id/id/ new-18625-detail-maklumat-pp-muhammadiyah-tentang-wabahcovid-19.html.

Qudsy, Saifuddin Zuhri, and Ahmad Sholahuddin. "Kredibilitas Hadis Dalam Covid-19: Studi Atas Bazl Al-Ma'un Fi Fadhil Al-Thaun Karya Ibnu Hajar Al-Asqalany." Al-Quds: Jurnal Studi Al-Qur'an Dan Hadis 4, no. 1 (2020).

Saenong, Fared F., and dkk. Fikih Pandemi: Beribadah Di Masa Wabah. Jakarta: NUO Publishing, 2020.

Setkab. "Minta Masyarakat Tenang Presiden Saatnya Bekerja Belajar Dan Beribadah Dari Rumah," 2020. https://setkab.go.id/mintamasyarakat-tenang-presiden-saatnya-bekerja-belajar-dan-beribadahdari-rumah/.

Shahih Bukhari. "Keutamaan Shalat Berjama'ah, Nomor Hadis 654,” n.d.

Shahih Muslim. "Keutamaan Di Mushola Setelah Shalat Shubuh, Nomor Hadis 288," n.d.

Keutamaan Shalat Isya Dan Shubuh Berjama'ah, Nomor Hadis 262 , n.d.

Shihab, M. Quraish. Corona Ujian Tuhan: Sikap Muslim Menghadapinya. Tangerang: Lentera Hati, 2020.

Shihab, Najwa. "Wabah Corona, Wajibkah Jumatan Dan Shalat Di Masjid?,” 2020.

Siegel, Ethan. "Tiga Cara Sains Membimbing Kita Melewati Pandemi Covid-19." In Wabah, Sains, Dan Politik, 3. Jakarta: Penerbit Antinomi, 2020.

Sunan Abi Dawud. “Ancaman Dalam Meninggalkan Shalat Jum'at Nomor Hadis 1052," n.d. 
Susilo, Adityo, and dkk. "Corona Virus Disease 2019: Tinjauan Literatur Terkini.” Jurnal Penyakit Dalam Indonesia 7, no. 1 (2020): 45.

Tasri. "Hikmah Di Tengah Wabah Virus Corona Dalam Tinjauan Hukum Islam." Qiyas 5, no. 1 (2020). 